Archetti, I., Donald, H. B., Isaacs, A. and Valentine, R. C. (1955). J. gen. Microbiol. 13, 330-337

\title{
The Effects of Metaperiodate and Heated Influenza Virus on Influenza Virus Growth
}

\author{
By I. ARCHETTI, HEATHER B. DONALD, A. ISAACS \\ AND R. C. VALENTINE
}

National Institute for Medical Research, Mill Hill, London, N.W. 7

\begin{abstract}
SUMMARY : Appropriate quantities of sodium metaperiodate injected into hen eggs inhibited the development of full infectivity by some strains of influenza virus, i.e, 'incomplete' virus was produced; with other strains of virus the same quantities of metaperiodate inhibited haemagglutinin production. Metaperiodate in a dose which of itself did not inhibit haemagglutinin production by two strains of influenza virus enhanced the inhibitory action of heated influenza virus on haemagglutinin production by these strains. Both sodium metaperiodate and heated influenza virus inhibited the production of influenza virus filaments more than that of spheres. It is suggested that both metaperiodate and heated influenza virus act on a common substrate which is required for the development of both viral agglutinin and full virus infectivity.
\end{abstract}

The growth of influenza virus in the chick embryo can be inhibited in two distinct ways; by partially or by wholly inactivated influenza virus. Firstly, virus wholly inactivated by heat at $56^{\circ}$ or by ultraviolet irradiation can cause inhibition of haemagglutinin production by influenza virus (Henle \& Henle, 1944); in this situation there is an inhibition in the yield of virus particles, but any particles produced are normally infective. Secondly, serial passages of influenza virus at low dilution (von Magnus, 1946), or the use of virus partially inactivated at $37^{\circ}$ (Horsfall, 1954) cause the production of virus with a low infectivity relative to the haemagglutinin titre ("incomplete' virus); in this case there is usually no diminution in the number of virus particles produced, but each particle has a very low probability of initiating infection. These two reactions are usually considered to be unrelated; they may be thought of as inhibitory actions on different stages of virus growth. von Magnus (1954) summarized the evidence for the hypothesis that infectivity is acquired late in virus development, and that 'incomplete' virus is immature in the sense that it is released from the cells without the virus having acquired the property of infectivity.

Recently, Fazekas de St Groth \& Graham (1954a) showed that in eggs treated with sodium metaperiodate and then inoculated with influenza virus, the virus produced had a low infectivity relative to the haemagglutinin titre, and thus corresponded to the incomplete virus of von Magnus (1946). These workers also showed that different strains of influenza virus varied in the ease with which they could be induced to form incomplete virus by serial passages at low dilution; the virus strains could be arranged in order of ease, and this order seemed to correspond roughly to a gradient of the affinity of the viruses for chorio-allantoic membrane receptor substance (Fazekas de St Groth \& 
Graham, 1954b). This was of great interest to us since previous results had suggested a similar correspondence between the affinity of viruses for chorioallantoic membrane receptor substance and the ease with which interference by heated influenza virus could be induced (Isaacs \& Edney, 1951). These findings suggested the possibility that the two inhibitory phenomena might be related. We have investigated the effects of sodium metaperiodate on different strains of influenza virus and our results, reported in this paper, show that an amount of sodium metaperiodate which inhibits the development of infectivity in one strain may inhibit agglutinin production in another. This supports the idea that the two inhibitory phenomena may be related. It will also be shown that there are some similarities in the action of sodium metaperiodate and heated influenza virus when tested as inhibitory reagents for different influenza virus strains.

\section{MATERIALS AND METHODS}

Virus strains. Influenza viruses PR 8, MEL and A/Persian Gulf/2/52 were kept in capillary tubes at $-70^{\circ}$. A/Persian Gulf/2/52 was used as 3rd or 4th egg passage material. Batches of virus were prepared by inoculating 10-day eggs by the allantoic route with $10^{3}$ to $10^{4} 50 \%$ egg-infective doses (EID 50) of seed virus and harvesting after incubation for $42 \mathrm{hr}$. at $35^{\circ}$.

Agglutination titrations. Agglutination titrations were carried out by a pattern test in plastic plates and the results expressed as the reciprocal of the initial dilution of virus at the partial agglutination end point. One agglutinating dose is defined as the least amount of virus required to agglutinate $0.25 \mathrm{ml}$. of a $1 \%$ suspension of washed chick red cells (about $10^{7 \cdot 1}$ to $10^{7 \cdot 2}$ cells).

Infectivity titrations. Serial 3·16-fold $(\sqrt{ } 10)$ dilutions of virus were prepared in broth-saline (50\% Hedley Wright broth in normal saline) and $0.05 \mathrm{ml}$. volumes inoculated into the allantoic sac of 10-day-old chick embryos, which were harvested after $\mathbf{7 2} \mathrm{hr}$. incubation at $35^{\circ}$ and tested for agglutinins. The end-points were calculated by the method of Reed \& Muench (1938) and the results expressed as EID 50/ml.

Experiments with metaperiodate. Eggs were treated with metaperiodate as described by Fazekas de St Groth \& Graham (1954a). Chick embryos (10-day) were inoculated in the allantoic sac with $1 \mathrm{ml}$. of $0.01 \mathrm{M}$-sodium metaperiodate. One hour later the excess metaperiodate was neutralized by an intra-allantoic inoculation of $0.25 \mathrm{ml} .0 \cdot 1 \mathrm{M}$-glycerol, and these eggs and control eggs were inoculated $2 \mathrm{hr}$. afterwards with the virus under test. The eggs were harvested after incubation for a further $42 \mathrm{hr}$. at $35^{\circ} \mathrm{C}$.

Interference experiments. Chick embryos (10-day) were inoculated in the allantoic cavity with inactivated influenza virus, as allantoic fluid heated at $56^{\circ}$ for $1 \mathrm{hr}$. $24 \mathrm{hr}$. later these and control eggs were inoculated with the virus under test and the eggs were harvested after a further $42 \mathrm{hr}$. incubation at $35^{\circ}$.

Virus counts on red cells. The numbers of virus filaments and spheres found in samples of allantoic fluid harvested from the treated eggs were counted on electron micrographs after adsorption on red cell membranes (Dawson \& Elford, 1949). The concentration of red cell membranes used for a particular 
absorption was dependent on the haemagglutinin titre of the virus examined. The allantoic fluid was spun lightly to remove debris, mixed with the laked red cell suspension and kept for $1 \mathrm{hr}$. at $5^{\circ}$. The cells were then fixed with $0 \cdot 1 \%$ osmium tetroxide for $30 \mathrm{~min}$., spun down and washed with distilled water at $5^{\circ}$, mounted on electron microscope grids and shadowed with gold manganin. Electron micrographs were taken of twelve or more red cells from each experiment at a magnification of about 5000 times and the numbers of filaments and spheres were counted and totalled for all the cells. The percentage of filaments in the sample was thus found. Assuming a random distribution of the two forms of virus, the standard error in this percentage will be that of a binomial distribution and is given by $\sqrt{ }(S F / N)$, where $N$ is the total number of virus particles, and $S$ and $F$ the percentages of spheres and filaments.

\section{RESULTS}

Effect of sodium metaperiodate on the ratio of infectivity to agglutinin in three strains of influenza virus

Fazekas de St Groth \& Graham (1954a) found that, in eggs treated with sodium metaperiodate and subsequently inoculated with high dilutions of the PR 8 and Lee strains of influenza virus, the virus produced had a significantly lower ratio of infectivity to agglutinin titre than when grown in normal untreated eggs. Our results in experiments of this type have been very variable with different strains of virus. Table 1 shows the ratios of infectivity to agglutinin titres of individual eggs inoculated with the MEL, PR 8 and A/Persian Gulf $/ 2 / 52$ viruses after pre-treatment with sodium metaperiodate.

Table 1. Effect of sodium metaperiodate treatment of eggs on the ratio (log) of infectivity to haemagglutinin titres in three strains of influenza virus

\begin{tabular}{|c|c|c|c|}
\hline Strain & Inhibitory agent & $\begin{array}{l}\text { Individual ID50/HA ratios } \\
(\log )\end{array}$ & $\begin{array}{l}\text { Mean ID50/HA } \\
\text { ratio }\end{array}$ \\
\hline MEL & $\begin{array}{l}\text { Metaperiodate } \\
\text { Nil-control }\end{array}$ & $\begin{array}{l}5 \cdot 5,5 \cdot 2,5 \cdot 0,6 \cdot 3,6 \cdot 0,5 \cdot 9 \\
5 \cdot 7,5 \cdot 9,6 \cdot 1,6 \cdot 2,6 \cdot 3,5 \cdot 7,5 \cdot 8\end{array}$ & $\begin{array}{l}5 \cdot 65 \\
5 \cdot 96\end{array}$ \\
\hline PR 8 & $\begin{array}{l}\text { Metaperiodate } \\
\text { Nil-control }\end{array}$ & $\begin{array}{l}5 \cdot 1,4 \cdot 9,4 \cdot 8,4 \cdot 9,5 \cdot 6,4 \cdot 9 \\
5 \cdot 6,4 \cdot 7,5 \cdot 0,5 \cdot 2,4 \cdot 9,4 \cdot 6,5 \cdot 2\end{array}$ & $\begin{array}{l}5 \cdot 03 \\
5 \cdot 03\end{array}$ \\
\hline A/Persian Gulf/2/52 & $\begin{array}{l}\text { Metaperiodate } \\
\text { Nil_control }\end{array}$ & $\begin{array}{l}5 \cdot 6,5 \cdot 4,5 \cdot 4 \\
4 \cdot 9,5 \cdot 8,5 \cdot 6,5 \cdot 4,5 \cdot 3\end{array}$ & $\begin{array}{l}5 \cdot 47 \\
5 \cdot 4\end{array}$ \\
\hline
\end{tabular}

Table 1 shows that metaperiodate treatment of the eggs has not induced any striking reduction in the ratio of infectivity to agglutinin titres of these viruses. The differences from the results of Fazekas de St Groth \& Graham $(1954 a)$ should be viewed in the light of two facts.

(a) The normal ratio of infectivity to agglutinin titre is about $10^{6.0}$ when calculated as described in Methods. Our PR8 and A/Persian Gulf/2/52 strains therefore show, in untreated eggs, ratios which are significantly lower than those of normal strains. Possibly, under those conditions, metaperiodate treatment of eggs does not reduce the ratio further. 
(b) With all three strains, but particularly with A/Persian Gulf/2/52 virus, metaperiodate treatment has caused a significant drop in haemagglutinin production in some eggs. This finding was not observed in the studies of Fazekas de St Groth \& Graham. In this connexion, the results with MEL virus are interesting. In most experiments with this strain, metaperiodate treatment did not reduce the yield of virus haemagglutinin, and the first three results with this strain, shown in Table 1 , indicated a slight drop in the ratio of infectivity to agglutinin titres on treatment with metaperiodate. In a later experiment, there was a significant drop in the yield of haemagglutinin with MEL virus, but the virus produced had a normal ratio of infectivity to haemagglutinin (see the last three results with MEL virus in Table 1). Our results suggest that metaperiodate treatment of eggs causes either a drop in the ratio of infectivity to agglutinin titres, or a reduced yield of haemagglutinin but not both effects at once.

\section{Effect of metaperiodate on the yield of virus haemagglutinin}

At different times metaperiodate has caused a significant drop in the yield of haemagglutinin with all three strains of influenza virus which we have investigated, but the effect was most regular with $\mathrm{A} / \mathrm{Persian}$ Gulf/2/52 virus. The results of a characteristic experiment are shown in Table 2.

Table 2. Effect of sodium metaperiodate treatment of eggs on the production of haemagglutinin by $A / P e r s i a n$ Gulf/2/52 virus

Inhibitory agent

Metaperiodate Nil-control
Haemagglutinin titres of individual eggs

$240,5,5,30,60,<1,5,100,<1,120,100,15,<1,30,40,80$ $240,320,60,240,320,320$

Table 2 shows haemagglutinin titres of individual periodate-treated eggs inoculated with A/Persian Gulf/2/52 virus and compared with untreated control eggs. The periodate-treated eggs show big variations in titre, from complete suppression of haemagglutinin production to no apparent effect when compared with the controls.

It was found that the metaperiodate action could be reversed by increasing the dose of virus; when undiluted virus (about 107 EID 50) was used there was no depression of haemagglutinin production. The reason for this finding is not at present clear.

\section{Combined action of metaperiodate and heated influenza virus on the yield of virus haemagglutinin}

In most of our experiments with PR 8 and MEL viruses, metaperiodate did not reduce the yield of virus haemagglutinin. However, when metaperiodate treatment, which of itself did not affect haemagglutinin yield, was combined with inoculation of heated influenza virus, the inhibitory effect of the latter was greatly increased. In order to show this, it was necessary to give the metaperiodate after the heated influenza virus; given before, this effect was 
absent. The result of an experiment which shows the combined action is given in Table 3.

Table 3. Effect of the combined action of sodium metaperiodate and heated Lee virus on haemagglutinin production by $\mathrm{PR} 8$ virus

\begin{tabular}{lc}
\multicolumn{1}{c}{ Inhibitory agent } & Haemagglutinin titres of individual eggs \\
2560 A.D. of heated Lee & $1280,80,640,<1,<1$ \\
Metaperiodate & $1600,2560,640,2560,2560,2560$ \\
2560 A.D. of heated Lee and metaperiodate & $8,<1,<1,<1,<1,<1$ \\
Nil-control & $2560,480,2560,1280,2560,1280$
\end{tabular}

The metaperiodate, which of itself did not inhibit haemagglutinin production by PR 8 virus in this experiment, enhanced the inhibitory action of heated Lee virus. This type of result has been obtained in many experiments with PR 8 and MEL used as challenge viruses and heated PR 8, MEL or Lee used as interfering viruses. We have not carried out experiments of this kind with A/Persian Gulf/2/52 virus, since this strain is much more sensitive than PR 8 or MEL, both to the action of metaperiodate, and to interference by heated influenza virus.

\section{Effect of heated influenza virus and metaperiodate on production of influenza virus filaments}

The bulk of the evidence available strongly supports the view that heated influenza virus inhibits virus growth at an intracellular site, i.e. the effect is on the virus multiplication within the cell (e.g. Henle, 1953). The fact that metaperiodate may inhibit the development of viral haemagglutinin or infectivity in different strains raised the possibility that this agent might also be blocking different stages of virus production within the cell. One method of gaining further information on this point was suggested by the known properties of influenza virus filaments. It has been shown that in the A/Persian Gulf/2/52 virus, filaments contain a higher proportion of haemagglutinin to infectivity than spheres, i.e. each filament has about the same probability of initiating infection as a sphere, but has a much greater efficiency in agglutinating red cells (Donald \& Isaacs, 1954). Any agent which inhibited the production of viral haemagglutinin might therefore be expected to depress filament production to a greater extent than production of spheres.

Preliminary experiments to test this point showed that when eggs were inoculated with A/Persian Gulf/2/52 virus after a preceding inoculation of heated influenza virus, virus filaments appeared to be scanty on electron or dark-ground microscopy. In order to obtain a quantitative estimate of the extent to which filament production was inhibited by heated influenza virus or metaperiodate relative to sphere production, the numbers of filaments and spheres adsorbed on suitable red cells were counted. For differentiating, a rod which was more than twice as long as it was broad was counted as a filament, and filament length was not taken further into account. The results of some counts are shown in Table 4. 
Table 4. Effect of sodium metaperiodate and heated influenza virus on the percentage of filaments produced by A/Persian Gulf/2/52 virus

\begin{tabular}{clccc} 
Exp. no. & \multicolumn{1}{c}{ Inhibitory agent } & $\begin{array}{c}\text { Haemagglutinin } \\
\text { titre of fluid } \\
\text { examined }\end{array}$ & $\begin{array}{c}\text { No. of particles } \\
\text { counted }\end{array}$ & $\begin{array}{c}\text { Percentage of } \\
\text { filaments }\end{array}$ \\
1 & 160 A.D. of heated MEL & 120 & 600 & $4 \pm 1$ \\
& Nil-control & 640 & 600 & $50 \pm 2$ \\
2 & 640 A.D. of heated PR 8 & 60 & 500 & $8 \pm 1$ \\
& Nil-control & 480 & 500 & $43 \pm 2$ \\
& Metaperiodate & 15 & 263 & $11 \pm 2$ \\
& Nil-control & 640 & 551 & $36 \pm 2$ \\
& Metaperiodate & 30 & 655 & $7 \pm 1$ \\
& Nil-control & 320 & 566 & $22 \pm 2$
\end{tabular}

It is clear that there has been a pronounced drop in the proportion of filaments to spheres as a result of pre-treating eggs with either sodium metaperiodate or heated influenza virus, and the differences from the controls are highly significant $(p<\mathbf{0 . 0 0 1})$ in each experiment. It seemed unlikely that this finding was due to the low agglutinin titres per se, since filaments are more efficient at agglutinating red cells than spheres and simple dilution should, if anything, increase the proportion of filaments. An experiment carried out to test this point showed no significant change in the proportion of filaments on diluting a preparation of virus ten times before adsorbing on to red cell ghosts.

The results of electron microscopy are illustrated in Pl. 1, figs. 1-4. There are roughly the same numbers of virus particles on each red cell, since the numbers of red cells used for the absorption were based on the agglutinin titre of each preparation. However, Pl. 1, fig. 1, shows that interference by heated influenza virus results in a decreased proportion of virus filaments to spheres compared with fig. 2 illustrating the corresponding control preparation; fig. 3 shows the effect of metaperiodate treatment, and again there is a decreased proportion of virus filaments to spheres compared with the corresponding control preparation in fig. 4.

\section{DISCUSSION}

These results show some interesting similarities in the inhibitory actions of heated influenza virus and sodium metaperiodate on the growth of influenza virus in the allantoic cavity of the chick embryo.

(a) A single dose of sodium metaperiodate may inhibit the development of full virus infectivity (i.e. cause the production of incomplete virus) in some strains, but inhibit haemagglutinin production in other strains. Similarly, influenza virus heated for $1 \mathrm{hr}$. at $56^{\circ}$ may inhibit the development of full virus infectivity without affecting haemagglutinin production (Horsfall, 1954); with larger doses of heated influenza virus it is more usual to find an inhibition of haemagglutinin production. In a number of investigations with these two inhibitory reagents, it has been found that there is either a decreased number of virus particles produced (inhibition of agglutinin production) but each par- 
ticle produced is normally infective; or there is a normal number of agglutinating particles produced but with reduced infectivity (i.e. incomplete virus).

(b) Sodium metaperiodate which of itself does not inhibit haemagglutinin production, enhances the inhibitory action of heated influenza virus.

(c) Both sodium metaperiodate and heated influenza virus inhibit the production of virus filaments more than that of spheres.

(d) A single dose of sodium metaperiodate inhibits the development of virus infectivity of different strains to a varying extent, corresponding with the affinity of different virus strains for chorio-allantoic membrane receptor substance. There appears to be a similar relationship for the inhibitory action of heated influenza virus on haemagglutinin production by different virus strains.

One theory which might cover these different observations is that there is a factor which is required for both the development of full virus infectivity and for the development of viral haemagglutinin, and that sodium metaperiodate and heated influenza virus owe their inhibitory activity to their ability to compete for this factor. Presumably, different strains vary in their requirements for this factor, and in any strain more factor is required for the development of full virus infectivity, since the development of infectivity is inhibited more readily than that of haemagglutinin. Such a factor (or factors) is unknown but one possibility which suggests itself is chorio-allantoic membrane receptor substance. This is known to be present in the chorio-allantoic membrane, but diminishes greatly during the first $24 \mathrm{hr}$. of influenzal infection (Edney \& Isaacs, 1950; Liu \& Henle, 1951). Subsequent increases and decreases in the content of membrane inhibitory titre coincide with decreases and increases respectively, in the rate of production of influenza virus from the membrane (Schlesinger, 1953). Heated influenza virus combines readily with chorio-allantoic membrane inhibitor and metaperiodate inactivates it. There is also evidence that this substance is required for the growth of influenza virus in the chick chorion (Depoux \& Isaacs, 1954). It is interesting that Ackermann \& Massaab (1954) have suggested that the action of influenza virus enzyme on this substrate may be necessary to complete the final stages of the release of fully infective virus from susceptible cells. It is suggested, therefore, that metaperiodate and heated influenza virus compete with the enzyme of active influenza virus for chorio-allantoic membrane inhibitor; and that this is the basis for their inhibitory effect on the development of haemagglutinin or of full virus infectivity by different strains of influenza virus.

We should like to thank Dr C. H. Andrewes, F.R.S., for his criticism and advice, and Mr E. Owen and Mr O. Green for their technical assistance. One of the authors (I.A.) is a W.H.O. Visiting Fellow at the World Influenza Centre.

\section{REFERENCES}

Ackermann, W. W. \& Massaab, H. F. (1954). Growth characteristics of influenza virus. Biochemical differentiation of stages of development. J. exp. Med. 100, 329.

Dawson, I. M. \& Elford, W. J. (1949). The investigation of influenza and related viruses in the electron microscope, by a new technique. J. gen. Microbiol. 3, 298. 
Journal of General Microbiology, Vol. 13, No. 2
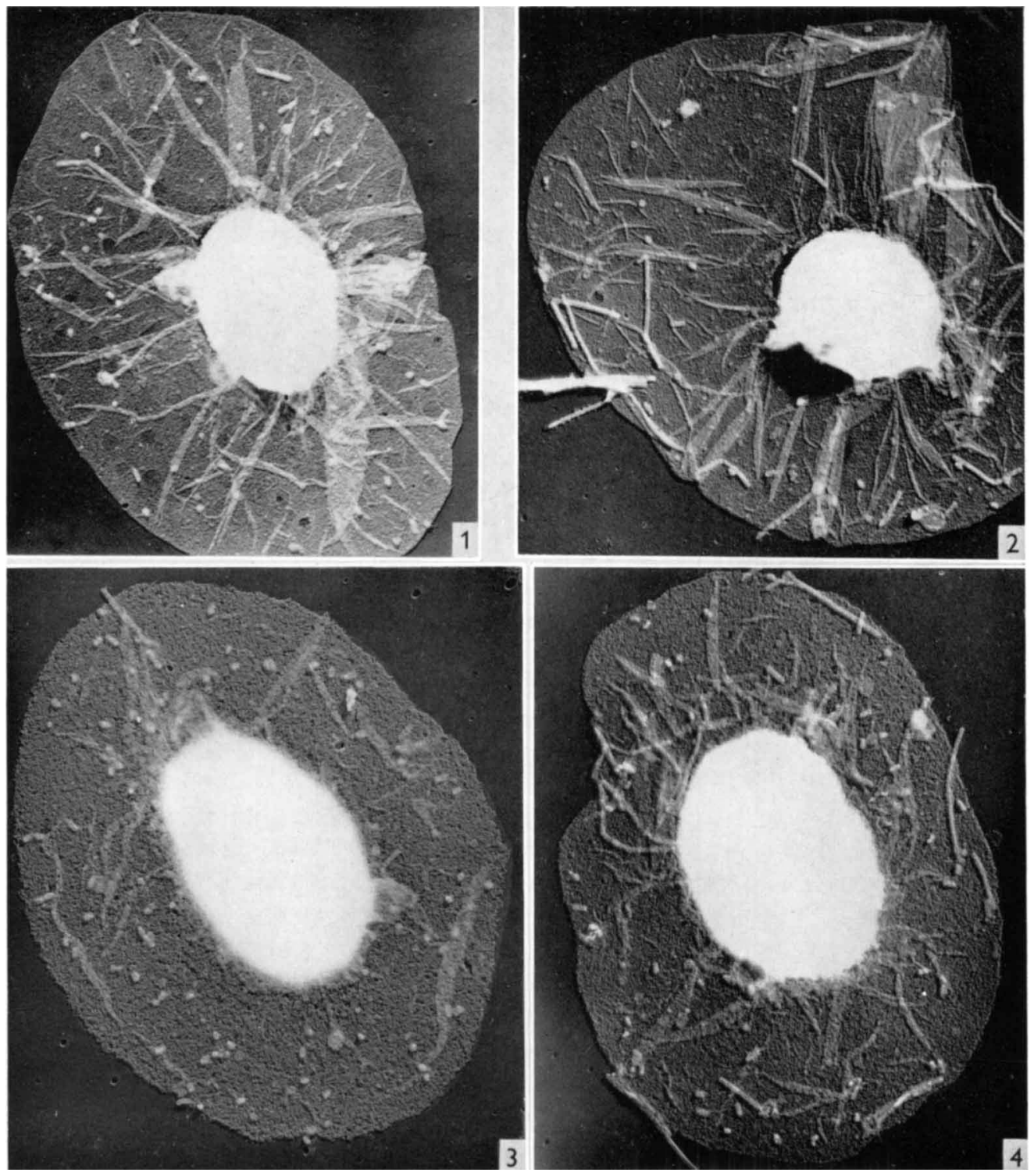

I. Archetti, H. B. Donalid, A. IsaAcs \& R. C. Valingtine-Inhibitors and influenza virus growth. Plate 1 
Depoux, R. \& IsaAcs, A. (1954). Effect of inhibitors on interference between influenza and vaccinia viruses. Brit. J. exp. Path. 35, 419.

Donald, H. B. \& Isaacs, A. (1954). Some properties of virus filaments shown by electron microscopic particle counts. J. gen. Microbiol. 11, 325.

EDNEy, M. \& IsAacs, A. (1950). Interference between inactive and active influenza viruses in the chick embryo. 3. Inhibitor of virus haemagglutination in the chorio-allantoic membrane. Aust. J. exp. Biol. med. Sci. 28, 603.

Fazekas de st Groth, S. \& Graham, D. M. (1954a). Artificial production of incomplete influenza virus. Nature, Lond., 173, 637.

Fazekas de st Groth, S. \& Graham, D. M. $(\mathbf{1 9 5 4} b)$. The production of incomplete virus particles among influenza strains: experiments in eggs. Brit. J. exp. Path. 35,60 .

Henle, W. (1953). In Advances in Virus Research, Vol. 1, p. 142. New York: Academic Press Inc.

Henle, W. \& Henle, G. (1944). Interference between inactive and active viruses of influenza. I. The incidental occurrence and artificial induction of the phenomenon. Amer. J. med. Sci. 207, 705.

Horsfall, JUn., F. (1954). On the reproduction of influenza virus. Quantitative studies with procedures which enumerate infective and haemagglutinating virus particles. J. exp. Med. 100, 135.

IsaAcs, A. \& EDNEy, M. (1951). Interference between inactive and active influenza viruses in the chick embryo. 5. The behaviour of different strains of challenge virus. Aust. J. exp. Biol. med. Sci. 29, 169.

Liv, O. C. \& Henle, W. (1951). Studies on host-virus interactions in the chick embryo-influenza virus system. 4. The role of inhibitors of haemagglutination in the evaluation of viral multiplication. J. exp. Med. 94, 269.

Magnus, $P$. von (1946). Studies on interference in experimental influenza. 1. Biological observations. Arkiv. Kemi Min. Geol. 24B, 1.

Magnus, P. von (1954). In Advances in Virus Research, vol. 2, p. 59. New York: Academic Press Inc.

ReEd, J. L. \& MUENCh, H. (1938). A simple method of estimating fifty per cent endpoints. Amer. J. Hyg. 27, 493.

Schlesinger, R. W. (1953). Multiplication and enzymic activity of influenza virus in infected tissues. In Interaction of viruses and cells. Symp. 6th Congr. int. Microbiol. p. 36.

\section{EXPLANATION OF PLATE}

Fig. 1. Influenza virus (A/Persian Gulf/2/52) adsorbed on a red cell ghost from egg treated with heated influenza virus, and showing a low proportion of filaments to spheres. Gold-manganin shadowed. $\times 14,000$.

Fig. 2. Control. As fig. 1 but without pre-treatment of egg. There is a high proportion of filaments to spheres. Gold-manganin shadowed. $\times 14,000$.

Fig. 3. Influenza virus (A/Persian Gulf/2/52) adsorbed on a red cell ghost from egg treated with metaperiodate, and showing a low proportion of filaments to spheres. Goldmanganin shadowed. $\times 12,000$.

Fig. 4. Control. As fig. 3 but without pre-treatment of egg. There is a high proportion of filaments to spheres. Gold-manganin shadowed. $\times 14,000$. 